\title{
Evaluation of Poor Area Understanding Under Cigarettes in Lebak District
}

\author{
*Nurhasanah, **Dumilah Ayuningtyas \\ *Faculty of Public Health Universitas Indonesia \\ * Department Health Administration and Policy, Faculty of Public Health Universitas Indonesia \\ Email:nunkhusna83@gmail.com
}

\begin{abstract}
Regional Regulation of Lebak District No.17 of 2006 on the Implementation of Order, Hygiene and Beauty is a derivative form of Government Regulation No.109 Year 2012 About Security of Materials Containing Addictive Substance in the form of Tobacco Products for Health. One of the mandate in the regulation is the establishment of NonSmoking Area (KTR) as an effort to protect the public against the health risks caused by the environment contaminated with tobacco smoke. Because health hazards caused by cigarettes not only affect the smokers but also passive smokers. WHO even mentioned that less than 6 million people died from smoking and exposure to cigarette smoke. The purpose of this research is to evaluate the implementation of KTR policy in Lebak District. This research uses Triangulation mix methode, data collection is done with qualitative and quantitative approach. The results obtained only a small percentage of people who adhered to the KTR policy (28\%), the community behaved positively for smoking (58\%) and high knowledge of cigarette and KTR hazards $(58 \%)$ and no relationship between behavior and knowledge ( $\mathrm{p}$ value $=0.075)$. Implementation of the policy of No Smoking Area has not been effective because there is still a difference between implementation and guidance in the use of Excise Revenue Sharing Fund from the Ministry of Health. Local governments have not been responsive to KTR policy with the issuance of Local Regulations on Non-Cigarette Regions, the formation of supervisory teams and socialization of local regulations. Recommendations that can be submitted are the issuance of Regional Regulations on Non-Smoking Areas, and the perception agreement of the use of Tobacco Revenue Sharing Funds on policy makers.
\end{abstract}

Keywords: no smoking area, evaluation, policy, district lebak

Abstrak. Peraturan Daerah Kabupaten Lebak No.17 Tahun 2006 Tentang Penyelenggaraan Ketertiban, Kebersihan dan Keindahan adalah bentuk turunan dari Peraturan Pemerintah No.109 Tahun 2012 Tentang Pengamanan Bahan Yang Mengandung Zat Adiktif Berupa Produk Tembakau Bagi Kesehatan. Salah satu amanat dalam peraturan tersebut ialah penetapan Kawasan Tanpa Rokok (KTR) sebagai upaya perlindungan masyarakat terhadap risiko gangguan kesehatan akibat lingkungan yang tercemar asap rokok. Sebab bahaya kesehatan akibat rokok tidak hanya berdampak pada perokok melainkan juga perokok pasif. WHO bahkan menyebutkan bahwa kurang dari 6 juta orang meninggal akibat rokok dan terpapar asap rokok. Tujuan dari penelitian ini ialah untuk mengevaluasi implementasi kebijakan KTR di Kabupaten Lebak. Penelitian ini menggunakan Triangulation mix methode, pengumpulan data dilakukan dengan pendekatan kualitatif dan kuantitatif. Hasil penelitian mendapatkan hanya sebagian kecil masyarakat yang patuh pada kebijakan KTR (28\%), masyarakat berperilaku positif untuk merokok (58\%) dan pengetahuan tinggi terkait bahaya rokok dan KTR (58\%) serta tidak ada hubungan antara perilaku dengan pengetahuan ( $p$ value = 0,075). Pelaksanaan kebijakan Kawasan Tanpa Rokok belum efektif karena masih adanya perbedaan antara implementasi dan pedoman dalam penggunaan Dana Bagi Hasil Cukai Hasil Tembakau yang dikeluarkan oleh Kemenkes RI. Pemerintah daerah belum responsif terhadap kebijakan KTR dengan belum diterbitkannya Peraturan Daerah tentang Kawasan Tanpa Rokok, pembentukan tim pengawas dan sosialisasi Perda. Rekomendasi yang dapat diajukan adalah penerbitan Peraturan Daerah tentang Kawasan Tanpa Rokok, dan penyamaan persepsi tentang penggunaan Dana Bagi Hasil Cukai Hasil Tembakau pada penentu kebijakan.

Kata kunci: kawasan tanpa rokok, evaluasi, kebijakan, Kab.Lebak

\section{INTRODUCTION}

Government Regulation No. 109 of 2012 on the safeguarding of substances containing addictive substances in the form of tobacco products for health states that non-smoking areas are rooms or areas that are prohibited for smoking activities or activities of producing, selling, advertising, and / or promoting tobacco products. In its implementation, the Government and the Regional Government are required to realize the Non Smoking Area.

Health hazards caused by cigarettes are not just the smokers, but also the health of passive smokers are more dangerous due to smoking. WHO says that $"<6$ 
million people die from cigarettes and are exposed to cigarettes (one person dies every 6 seconds)) (www.who.int /gho /tobacco /en.) Therefore, the establishment of Non-Smoking Area is an appropriate step to protect people against the risks of health problems due to the environment contaminated with tobacco smoke. (http://dinkes.tabalongkab.go.id /2014/12/kawasan-tanpa-rokok/).

Non-smoking areas are built not to deter people from smoking, but only restrict areas that are not allowed to smoke because the impact of the cigarette is in addition to harm your own health is also detrimental to the health of others as passive smokers. The enactment of non-smoking areas is not without reason, worldwide, an estimated 33 percent of men and 35 percent of nonsmokers are exposed to regular exposure to secondhand smoke, in many countries, passive smokers exposed to other people's cigarette smoke at work and as many as 40 percent of children exposed to secondhand smoke in public places. People exposed to secondhand smoke make them passive smokers who have the same dangers as active smokers themselves. Some of the dangers of being a passive smoker include lung cancer, heart disease, low birth weight babies, and chronic lung diseases such as bronchitis, and other health problems.

There is no safe level of exposure to secondhand smoke for non-smokers. Every year 600,000 passive smokers die. Of all premature deaths of passive smokers, as many as 47 percent $(281,000)$ occurred among women and 28 percent $(166,000)$ occurred in children. Passive smokers are at risk of lung cancer by 20-30 percent, coronary heart 25-30 percent and acute coronary heart 25-35 percent (http://www.kompak.co/kawasan-tanparokok/).

Lebak District is an area categorized as lagging, its territory is spread with geographical condition that varies from start of mountains to coastal area can be found in this district.

The regulations issued by the Government in 2012 can not be implemented in Lebak District, because although the regulation mandates the existence of Regional Regulations specifically discussing the Non-Smoking Area but in reality the ongoing Regional Regulation is a general rule that is the Regional Regulation Lebak No 17 of 2006 on the Implementation of Order, Cleanliness and Beauty which in article 24 paragraphs 1 and 2 mentions that the existence of Non Smoking Area and the smoking ban in the area then continued with the publication of the circulation on smoking ban in any place No.180 of 2010 issued by Local Government of Lebak District.

With the policy of No Smoking Area, the Local Government of Lebak District seeks to realize a special area of smoking despite the circumstances that have not met the criteria mentioned in the implementation of the KTR itself. However, when the area for smoking has started to be established and no smoking regulations are in place, there are still some people who disregard the rule by smoking in any place. Therefore, the Public Health Service made several efforts related to the prohibition of smoking in any place by advocating, socializing and issuing regulations and strengthened by the development of behavior of promotive-preventive efforts in health development (Lebak Health News, 2015). Based on the problems mentioned above, the authors are interested to conduct research on the impact resulting from the implementation of the policy of NonSmoking Area that has been implemented in Lebak District since 2006. This research is generally aimed to evaluate the implementation of the policy of NonSmoking Area in Lebak District.

\section{METHOD}

This research use mix method with qualitative and quantitative approach. Primary data was obtained by conducting in-depth interviews to dig deep information about the impact of the implementation of the policy of No Smoking Area in Lebak District based on Lebak District Regulation No.17 of 2006 on Implementation of Order, Cleanliness and Beauty, while secondary data obtained from the study of Implementation Document Budget and annual reports of activities.

Prior to in-depth interviews, observations were made to see the implementation of the No Smoking Regions policy at the moment by using observation sheets and distributing questionnaires to Lebak communities residing in Non-Smoking Areas. The sample used in this research is 100 people with sampling technique done by nonprobability sampling, that is by incidental sampling where the sample determination by chance. While in-depth interviews were conducted to all informants consisting of 8 Head of Puskesmas Rangkasbitung, Head of STIE La-Tansa Mashiro, Management of Children Playground, Al-Araf Mosque Management, responsible for KJU Bus pool, Head of Rangkasbitung Station, Asda IV Pemda Lebak, and Head of Health Office and conduct document review at related institution.

The data are tested for validity by doing triangulation which is analyzed and presented in narrative form. The study was conducted by the researcher himself and an assistant during an in-depth interview in May 2016 in Lebak District, Banten Province.

\section{RESULTS AND DISCUSSION}

Broadly speaking, the evaluation of the implementation of the policy of Non-Smoking Area in Lebak District is seen from its effectiveness. To achieve organizational effectiveness in building success in the era of regional autonomy depends on the effectiveness of the agencies 
as local government institutions that are present to serve the community and place the community as shareholders, so it needs serious attention in providing services. All of them require executing officers who have cooperative relationships to achieve organizational goals that have been established based on the vision, mission and strategic plan of the organization (Tangkilias, 2005). The effectiveness of this Non-Smoking Regions Policy is seen from the allocation of regional budgets in the implementation of the Non-Smoking Zone policy and its responsiveness to the policy.

Based on Government Regulation no. 78 year 2014 on the Acceleration of Development of Disadvantaged Regions, Lebak District is included in the category of disadvantaged areas in Banten Province due to the people's economy, human resources, facilities and infrastructure, regional financial capability, accessibility and regional characteristics (setkab.go.id accessed on $26 / 5 / 2016)$. In carrying out the NonSmoking Area the Lebak District Government has made every effort to succeed the beneficial government programs and will improve the health status of the people in Lebak District in particular and in Indonesia in general.

Knowledge, behavior and budget are the three elements that researchers regard as the reason for the ineffectiveness of No Smoking Regions policy in Kabupaten Lebak. The big budget in the health sector does not make the Lebak District government able to implement the policy of No Smoking Area properly, due to the use and utilization of the budget that is not understood correctly by each party to the policy makers in Lebak District.

According to the report on the use of tobacco excise duty funds in 2015 by Lebak District Health Office, the funds that have been used and utilized amounted to Rp. 17.194.621.140, - (seventeen billion one hundred ninety four million six hundred twenty one thousand one hundred forty rupiah). Five programs and twelve health activities funded by the tobacco tax fund are: 1) health promotion and community empowerment program Rp.885.206.000, - used to finance the promotion of promotional media and conscious information of healthy living, 2) health efforts program Rp 3,000,000,640 for health care activities, 3) health service standardization program of Rp.330.000.640, used to finance development activities and updating of basic data on health service standards, 4) procurement programs, upgrading and repair of sarrana and infrastructure of Puskesmas / Puskesmas pembantu and network amounting to Rp.9.948.864.500, - used to finance 8 types of activities, namely: procurement of facilities and infrastructure Puskesmas, provision of facilities and infrastructure Puskesmas Pembantu, Routine / periodic maintenance of facilities and infrastructure Puskesmas Pembantu, procurement of mobile clinic and operational vehicle, rehabilita the housing, rehabilitation and construction of sub health center, rehabilitation of health center and health center, 5) maternal and maternal health improvement program Rp.100.000.000, - used to finance the improvement activity of adolescent health.

Regional Budget (APBD) according to Law No.32 of 2004 on Regional Government is an annual financial plan of local government which is determined by local regulations. Article 157 states that the source of regional income consists of: a. local revenue, hereinafter referred to as PAD, namely: 1) the result of local taxes; 2) the result of regional retribution; 3) the result of separated regional wealth management; and 4) other legitimate PAD; b. balance funds; and c. other legitimate regional income. The budget allocated for the implementation of the policy of No Smoking Area in Lebak District is still minimal even though the amount of budget for health is quite large. Five programs with twelve activities in the field of health that have been done are still not maximally used for the implementation of the policy of No Smoking Area so it appears that there is a gap between implementation with guidelines on the use of Tobacco Excise Revenue Fund (DBHCHT).

Based on the results of the research, programs and activities funded by this DBHCHT can only be done partly by Lebak District, this is due to lack of understanding of the planning in the Health Office about the planning activities set by the Ministry of Health through the guidance of the use of DBHCHT so that planned activities and realized only a small part.

Some of the activities set out in the DBHCHT guidelines include: 1) the establishment of NonSmoking Areas and the procurement of special places for smoking in public places by (a) seeking to make Regional Regulations on Non-Smoking Areas; (b) disseminating information on Non-Cigarette Areas (d) monitoring and evaluating the application of NonSmoking Zones; and 2) availability of health care facilities for patients affected by tobacco smoke by (a) improving access to early detection of the impact of secondhand smoke on both passive and active smokers, (b) increasing access to behavioral rehabilitation counseling both in active and passive smokers, (c) providing health facilities and infrastructure for both active and passive smokers.

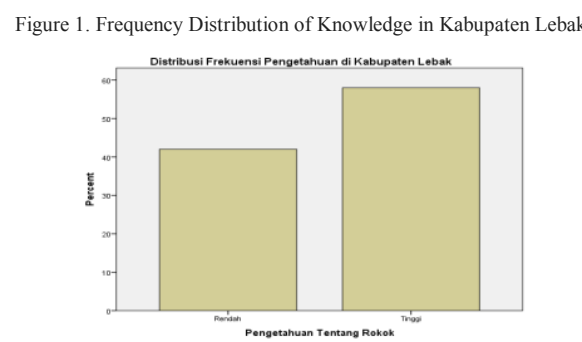




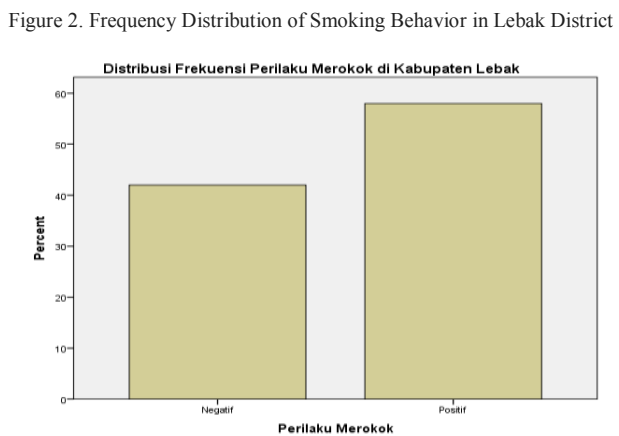

According to Lawrence Green, which affects a person in health behavior are: Predisposing factors, these factors include knowledge and attitudes of society on health, traditions and beliefs of the public on matters relating to health, community value systems, educational level, socioeconomic level and so on. The enabling factor, these factors include the availability of facilities and infrastructure or health facilities for the community such as Puskesmas, hospitals, polyclinics, posyandu, polindes, village drug posts, doctors or private practice midwives. The reinforcing factor, these factors include attitude and behavior factors of community leaders, religious leaders and health workers.

Result of research got that knowledge not related to behavior $p$ value 0,075 , this is same with research conducted by Ratih Sufra Rizkani about Knowledge Relation with Assertive Behavior of Nurse in Establishing Interpersonal Relationship in Inner Room of Mawar and Nusa Indah RSUD. dr. Djulham Binjai that there is no significant relationship between knowledge with the assertive behavior of nurses in fostering interpersonal relationships in the rosettes and nusa indah hospitals. dr. Djulham Binjai ( $p$ value $=$ $0.350)$.

In this case the researchers argue that the high knowledge of a person does not affect the behavior or habits in smoking activities. Because smoking behavior is not behavior based on one's knowledge of the dangers of cigarettes or non-smoking areas, but smoking behavior is a habit that has become a habit and inherent in general Indonesian people who make someone addicted so that when someone tries to stop smoking must pass a period called cigarette widthdrawal syndrom.

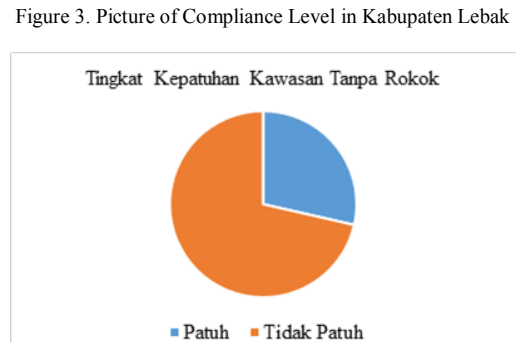

Measuring the responsiveness of bureaucracy to the expectations, desires, aspirations, and demands of the community is an act of government responsiveness. Responsiveness is also required in the implementation of policy implementation. Responsiveness is a performance indicator because it directly describes the ability of public orgasnisasi in carrying out its mission and objectives, especially to meet the needs of the community. Low responsiveness is indicated by the dissonance between service and community needs.

The form of information delivery to the community becomes an important part in the implementation of the policy of No Smoking Area. The result of the research shows that most of the people do not know the local regulation that regulate Non-Smoking Area in Lebak District even though local regulation has been going on for about 10 years since 2006. This happened because of lack of government innovation in giving such information. Communities know the rules on smoking bans or the Smoking Area are limited to the warning signs of smoking bans attached to the places they attend, not from the knowledge they have after they get counseling.

The diagram above shows that most people in Lebak District do not obey the Regulation of Non-Smoking Area which means not yet maximum responsiveness of local government to the implementation of policy of Non Smoking Area. The results of observation of compliance level conducted on the leaders or managers in each Non-Smoking Area have scores that are mostly less than the median value (5). This can be interpreted that most of the No Smoking Area in Lebak District still has not considered the importance of implementing the policy of No Smoking Area as their obligation.

Based on the theory of responsiveness, the Regional Government as a public organization must be able to meet the needs of the community. in this case is the implementation of the policy of No Smoking Area. Local governments should have clarity of programs. The clarity of the program in question can be in the form of regulations that specifically regulate the NonSmoking Area, the source of funds used in the implementation, guidelines on the implementation of Non-Smoking Area, Non-Smoking Regulatory Team and form of sanction given in case of violation.

The responsiveness of local government to the nonsmoking area policy is still lacking because of the obstacles found in the implementation of the policy such as the absence of maximum supervision. Although in writing there is Satuan Polisi Pamong Praja as a regional apparatus in charge of enforcing all local regulations. However, this will not work well if it is not supported by good cooperation between the head of the Regional Work Unit as the responsible and 
policy makers in the local agencies.

The lack of government innovation in providing information related to the Non-Smoking Area is also a problem because people only know the rules about smoking bans or the Smoking Area are limited to the warning signs of smoking bans attached to the places they attend, not from the knowledge they have after they get counseling. Therefore, counseling about the dangers of cigarettes and smoking ethics can raise awareness that smoking behavior in any place can endanger others, so smokers are willing to carry out their activities in specially designated smoking areas.

\section{CONCLUSION}

From the results ofresearch and discussion obtained, it can be concluded as follows:

1. The implementation of the policy of Non-Smoking Area in Lebak District were not yet firm, which is marked by the unspesificied local regulation on Non Smoking Area.

2. Not all Non-Smoking Areas implement the policy of No Smoking Area.

3. The ineffectiveness of implementation of policy of Non Smoking Area implemented in Lebak District causes by the difference of perception among stakeholders regarding the use and utilization of Excise Revenue Sharing Fund of Tobacco Products.

4. The use of Shared Revenue Sharesof Tobacco Products related to the policy of No Smoking Area is not maximized yet.

5. Lebak District Government unresponsive to the policy of Non-Smoking Area showed by less reglation enforcement by Police Unit of Pamong Praja.

6. Lack of government innovation in providing information related to No Smoking Regions Policy.

Based on the results of research and researcher's analysis on this research, the recommendations than can be submitted by researchers are:

1. Make a special Region Regulation on NonSmoking Area

2. Imposing strict sanctions if a Non-Cigarettes Area did not perform its functions

3. Establish a team of non-cigarette region supervisors and incentives to carry out their duties in order to improve compliance with the policy of No Smoking Area in Lebak District

4. Build networks among stakeholders initiated by the local government, DPPKD, Health Office and Health Promotion Field of Public Health Serice to better perception agreement about the use or utilization of excise tax revenue sharng fund of tobacco products

5. Build and improve external communication among leaders of Non-Smoking Zones with Policy Makers so that there is a joint commitment in the implementation of the policy of Non-Smoking Area in Lebak District.

6. Implementation of edutainment in the socialization of the policy of Non-Smoking Area to each leader of Non-Smoking Area and the community so as to attract attention and have the desire to realize Non Smoking Area in Kabupaten Lebak.

\section{REFERENCES}

Aditama Tjandra Yoga, (1992), Rokok dan Kesehatan, Universitas Indonesia Press, Jakarta.

Badan Penelitian dan Pengembangan Kesehatan, (2009), Laporan Hasil Riset Kesehatan Dasar (RISKESDAS) Provinsi Banten Tahun 2007, Jakarta.

Badan Penelitian dan Pengembangan Kesehatan, (2013), Laporan Hasil Riset Kesehatan Dasar (RISKESDAS) Tahun 2013, Jakarta.

Budi Winarno, (2014), Kebijakan Publik Teori Proses dan Studi Kasus, CAPS, Yogyakarta.

Dinas Kesehatan Kabupaten Lebak, (2016), Laporan Pemanfaatan Dana Bagi Hasil Cukai Hasil Tembakau Tahun 2015. Rangkasbitung.

Nugroho Riant, (2014), Public Policy, Elex Media Komputindo, Jakarta.

Republik Indonesia, (2012), Peraturan Pemerintah RI Nomor 109 Tentang Pengamanan Bahan Yang Mengandung Zat Adiktif Berupa Produk Tembakau Bagi Kesehatan, Jakarta.

Pusat Promosi Kesehatan, (2012), Panduan Penggunaan Dana Bagi Hasil Cukai Hasil Tembakau Di Bidang Kesehatan, Jakarta.

Sugiyono, (2011), Metode Penelitian Kuantitatif Kualitatif Dan R E $D$, Alfabeta, Bandung.

TCSC-IAKMI, (2012), Buku Bunga Rampai Fakta Tembakau Dan Permasalahannya di Indonesia Tahun 2012, Jakarta.

TCSC-IAKMI, (2013), Atlas Tembakau Indonesia, Jakarta. 